Review of
ECONOMICS
and
INSTITUTIONS

\title{
Productivity Growth in Europe and the US: aSectoral Study
}

\author{
Mary O'Mahony \\ University of Birmingham, \\ NIESR London
}

\author{
Ana Rincón-Aznar ${ }^{凶}$ \\ NIESR London
}

\author{
Catherine Robinson \\ University of Swansea, \\ NIESR London
}

\begin{abstract}
This paper describes recent trends in productivity growth in the EU and the US. By adopting a sectoral perspective, we achieve a deeper understanding of the compositional patterns of aggregate growth and shed light on the reasons why the EU productivity has lagged behind the US during the period 1995-2007. This may be of use for policy makers in order to design policies to close the gap. Whilst our findings indicate that performance in manufacturing sectors of many EU countries has been strong, we observe notable disadvantages in relation to productivity performance of key market service sectors. Restrictions in product and labour markets prevailing in many EU countries have been put forward as potential factors causing poor productivity; research shows that these can have particular harmful effects in services sectors given their large size and inter-linkages to other sector of the economy.
\end{abstract}

JEL classification: E01, E23, O47

Keywords:productivity, growth, service sectors

\section{Introduction}

The slowdown in European growth in the late 1990s is now well documented (van Ark et al., 2008), however, the source of this divergence in productivity growth relative to the US has generated considerable discussion in recent years. The advent of the EU KLEMS database has

Part of the work was done within the European Commission project B2/ENTR/05/091FC and was financed under the Competitiveness and Innovation Framework Programme (CIP) which aims to encourage the competitiveness of European enterprises. The support of the European Commission is therefore gratefully acknowledged.

${ }^{\square}$ Corresponding author. Address: NIESR - National Institute of Economic and Social Research, 2 Dean Trench Street, Smith Square London, SW1P 3HE. (Phone: +44-2076541953; Fax: +44-20-76541900; Email: arincon@niesr.ac.uk)

\section{Recommended Citation}

O’Mahony, M., Rincón-Aznar, A., \& Robinson, C. (2010). Productivity growth in Europe and the US:A Sectoral Study. Review of Economics and Institutions, 1 (1), Article 5. doi:10.5202/rei.v1i1.5

Retrieved from http://www.rei.unipg.it/rei/article/view/5 
enabled a much more detailed understanding of the nature of differences across countries; its sectoral perspective allows the consideration of detailed trends and patterns across industries and countries over time.

O'Mahony and Timmer (2009) provide evidence of the productivity gap between the US and Europe, identifying three major sources. Firstly, the investment in Information and Communication Technologies (ICTs). This has been an area of research for a number of studies that focussed on the 1990s gap (O'Mahony and van Ark, 2003). They also identify more recent concerns in the literature as the divergence in skills in the two regions, a necessity for effectively exploiting the new ICT technology. This has been the focus of a number of studies that have considered the importance of skill biased technological change (Autoret al., 1998). Finally, they identify the difference in the multi-factor productivity between the US and the EU. MFP encapsulates all the unidentified factors that contribute to labour productivity growth and the growth in this component is likely to indicate an increase in un-measurable factors such as intangible assets, thought to be composed of factors such as innovative activity and organisational capital (Basuet al., 2003).

More recently, the role of reallocation in multifactor productivity growth is emphasized by Arnold et al. (2010), who argue that some heavily-regulated economies are less able to channel resources towards the most dynamics sectors and firms. Ultimately, this may have an effect on the potential for "creative destruction" and efficient reallocation of resources in the economy. This, they argue, has resulted in superior productivity performance of countries such as the US, Australia and certain smaller European countries over the last decade, a period characterised by the emergence and spread of innovative technologies such as the ICTs. Arnold et al., argue that unnecessary regulatory burdens hinder productivity improvements especially for firms far from the frontier but who are catching-up.

In this paper, we utilise the latest version of the EU KLEMS database to focus on the following questions:

- Which sectors have experienced high (low) labour productivity growth in recent years in comparison with the US?

- What is the aggregate labour productivity gap between the US and the EU, and which are the sectors that contribute most to this difference?

- What is the role that the inputs to the production process play across sectors, and more importantly, to what extent performance of multi factor productivity contributes to explain differences in sectoral growth?

This study focuses on a detailed sectoral comparison of the EU as a whole with the US. We present figures for several EU aggregates that may 
be relevant from a policy point of view. These are the EU25, consisting of all EU countries, excluding Bulgaria and Romania; the New Member States, that consist of those (other than Romania and Bulgaria) that most recently joined the EU - Cyprus, The Czech Republic, Estonia, Hungary, Lithuania, Latvia, Malta, Poland, Slovenia and The Slovak Republic (hereafter NMS10). We also group the longer standing members of the European Union (hereafter the EU15). Data for the full set of growth accounts are only available for a selection of ten European countries, called the EU-15ex aggregate according to the EUKLEMS nomenclature. The EU-15ex is comprised of Austria, Belgium Denmark, Spain, Finland, France, Germany, Italy, the Netherlands and the UK. The paper concentrates on the EU as a whole but we provide some country level detail.

The paper is organised as follows: Section 2 outlines the basic growth accounting methodology on which EU KLEMS is based, explaining how productivity measures have been calculated. In section 3 we briefly review recent evidence on labour productivity trends at the country level in Europe and the US. In section 4 we concentrate on sectoral labour growth using the latest version of the EU KLEMS database. We go on to outline the main trends in multifactor productivity growth in section 5 . In section 6 we draw conclusions on the nature of the aggregate productivity gap between Europe and the US, given our findings from EU KLEMS and in light of recent literature.

\section{Measuring Productivity}

A recent report by the European Commission (2009) highlights that while the current economic downturn is to a large extent a short-term phenomenon, the situation in some sectors has been aggravated by preexisting low productivity performance. Given this, we recognise that it is important to consider developments in productivity, which alongside unit labour costs from a domestic perspective and trade-related measures from an external one, are considered key long-term drivers of competitiveness. In this paper we analyse both labour productivity (LP) and multifactor productivity growth (MFP).

Labour productivity is defined as gross value addedper worker-hour. To estimate MFP growth rates a growth accounting technique has been employed to quantify the respective importance of different kinds of factor accumulation for productivity growth (equation 1). It has been employed extensively in national and international comparisons of productivity growth rates and levels, e.g. in Jorgenson, Gollop and Fraumeni (1987), O’Mahony (1999), O’Mahony and van Ark (2003). 
Under the assumptions of competitive factor markets, full input utilization and constant returns to scale, the growth of output can be expressed as the cost-share weighted growth of inputs and technological change $\left(A^{Y}\right)$, using the translog functional form common in such analyses ${ }^{1}$ :

$\Delta \ln Y_{j t}=\bar{v}_{j t}^{K} \Delta \ln K_{j t}+\bar{v}_{j t}^{L} \Delta \ln L_{j t}+\Delta \ln A_{j t}^{Y}(1)$

where $\bar{v}_{j t}{ }^{K}$ denotes the two-period average share of capital input in value addedand $\bar{v}_{j t}^{L}$ the two period average share of labour in value added.

It is common to define aggregate input, say labour, as a Törnqvist quantity index of individual labour types as follows:

$$
\begin{aligned}
& \Delta \ln L_{j t}=\sum_{l} \bar{w}_{l, j t}^{L} \Delta \ln L_{l, j t}(2) \\
& \Delta \ln K_{j t}=\sum_{k} \bar{w}_{k, j t}^{K} \Delta \ln K_{k, j t}
\end{aligned}
$$

where $\Delta \ln L_{l, t}$ indicates the growth of hours worked by labour type and weights are given by the period average shares of each type in the value of labour compensation, and similarly for $\mathrm{K}$. Thus the contribution of the capital is given by the product of its share in total costs and its growth rate. The contribution of labour input is split into hours worked and changes in the composition of hours worked.Any remaining output growth is picked up by the multi-factor productivity term A.

In our analysis we employ value added as a measure of output. It is often argued that the use of value added at the industry level can yield biased estimates of MFP, as it ignores changes in the contributions of intermediate inputs. A value added specification however has the advantage that it is straightforward to aggregate industry MFP growth rates or relative levels to some aggregate, e.g. to aggregate manufacturing. A methodological point that should be made is the influence of business cycles on measures of productivity. Undoubtedly, in economic downturns productivity is reduced as capacity is underutilised. This has become all

${ }^{1}$ To be more precise, A reflects Hicks-neutral technical change. Because of our approach to capital measurement, it only includes disembodied technical change.

2 Aggregate input is unobservable and it is common to express it as a translog function of its individual components. Then the corresponding index is a Törnqvistvolume index (see Jorgenson et al., 1987). 
the more pertinent in recent years, with the global downturn, the repercussions of which have yet to be fully realised.

EU KLEMS contains data on the EU aggregates under consideration for the period 1995-2007. The level of sectoral disaggregation in the latest version of EU KLEMS is approximately A31 (30+ industries). It is perhaps also worth noting that, by and large, we avoid commenting on public sector industries. This is partly because measurement is difficult and partly because the institutional arrangements vary significantly across countries and regions, thus European aggregation and in turn US comparisons are not easily made. The full sectoral list is provided in the tables in Section 4.

\section{Productivity Trends at Country Level}

The overall picture of aggregate growth within Europe is presented in Table 1 for the period 1995-2007, highlighting the substantial variation in measures of productivity amongst member states. The average annual percentage growth rates of labour and multi factor productivity are presented and contrasted with the US position for all member states of the EU25 (excluding Romania and Bulgaria from the full EU membership). We observe high productivity growth rates amongst New Member States, predominantly the result of the restructuring of their economies and catching-up. Amongst the "old" EU member states, there is considerable diversity in growth experience in recent years. A number of EU countries have seen relatively fast rates of growth; these are Finland, Sweden and the UK. The "Old" EU15 countries show relatively low levels of productivity growth relative to the US. For example, a few countries such as Italy, Spain, Denmark and Luxembourg show high labour productivity growth rates but negative multifactor productivity growth rates. Relative to the US, labour productivity growth in many of the NMS10 is considerably higher ${ }^{3}$. In the case of the New Member States aggregate, the data only cover the period up to 2006, since 2007 data were not available for Slovenia or Poland.

\footnotetext{
${ }^{3}$ We note that the highest labour productivity growth was experienced by New Members States such as Estonia, Latvia and Lithuania.
} 
Table 1 - Average Productivity Growth by Country, 1995-2007*

\begin{tabular}{|c|c|c|c|c|}
\hline & \multicolumn{2}{|c|}{ Labour productivity } & \multicolumn{2}{|c|}{ Multi Factor Productivity } \\
\hline & Growth (\%) & Difference to US & Growth (\%) & Difference to US \\
\hline Austria & 1.62 & -0.31 & 0.89 & 0.30 \\
\hline Belgium & 1.11 & -0.82 & - & - \\
\hline Cyprus & 1.93 & 0.00 & - & - \\
\hline Czech Republic & 2.96 & 1.03 & 0.63 & 0.04 \\
\hline Germany & 1.72 & -0.20 & 0.68 & 0.09 \\
\hline Denmark & 0.63 & -1.30 & -0.28 & -0.87 \\
\hline Estonia & 7.70 & 5.78 & - & - \\
\hline Spain & 0.54 & -1.38 & -0.69 & -1.28 \\
\hline Finland & 2.28 & 0.36 & 1.55 & 0.96 \\
\hline France & 1.62 & -0.31 & 0.61 & 0.02 \\
\hline Greece & 2.30 & 0.37 & - & - \\
\hline Hungary & 3.52 & 1.60 & 2.42 & 1.83 \\
\hline Ireland & 3.56 & 1.63 & - & - \\
\hline Italy & 0.42 & -1.50 & -0.29 & -0.88 \\
\hline Lithuania & 5.79 & 3.87 & - & - \\
\hline Luxembourg & 0.99 & -0.93 & -0.17 & -0.76 \\
\hline Latvia & 6.16 & 4.23 & - & - \\
\hline Malta & 2.09 & 0.16 & - & - \\
\hline Netherlands & 1.51 & -0.41 & 0.58 & -0.01 \\
\hline Poland & 4.27 & 2.35 & 2.60 & 2.01 \\
\hline Portugal & 1.58 & -0.35 & - & - \\
\hline Sweden & 2.35 & 0.42 & 0.78 & 0.19 \\
\hline Slovenia & 4.26 & 2.33 & 0.90 & 0.31 \\
\hline Slovak Republic & 4.39 & 2.46 & - & - \\
\hline UK & 1.87 & -0.06 & 0.42 & -0.17 \\
\hline US & 1.93 & 0.00 & 0.59 & 0.00 \\
\hline NMS10 & 1.42 & -0.51 & - & - \\
\hline EU-15ex & 1.70 & -0.23 & 0.36 & -0.23 \\
\hline EU15 & 3.54 & 1.61 & - & - \\
\hline EU25 & 1.34 & -0.58 & - & - \\
\hline
\end{tabular}

*Note that for Slovenia, Portugal and Poland, data only run to 2006. Consequently, the NMS aggregate covers up to 2006 only.

Source: EUKLEMS, November 2009 release. Own calculations.

Recent research (McMorrow and Röger, 2007) explores the labour market positions of European nations, noting improvements in the way in which the labour market functions that have not been matched by improvements in productivity. This, they argue, is evidence of a worrying divergence in growth patterns amongst developed countries. Generally there is the perception that EU member states need to shift their focus from lower productivity sectors to those that have a higher productivity growth prospect, and that the barriers to this reallocation lie chiefly in restrictive labour and product markets. The degree to which reallocation is 
taking place is thus of great interest to European economists and policy makers. Researchers in the field recently have linked existing crosscountry differences in productivity to differences in institutions and the regulatory environment. The main conclusion emerging is that restrictions in the regulatory environment that hamper the business environment seem to have a detrimental impact on sectoral productivity. The literature provides us with considerable evidence that regulatory reform is thus likely to improve competition and productivity at the market level, and innovation and investment at the firm level.

Inklaaret al. (2008) focus on the developments of market services productivity and find that lower regulatory barriers to entry in post and telecommunications had a positive influence on MFP growth demonstrating that policies to facilitate market entry of new firms may stimulate competition and increase total factor productivity. Arnold et al., (2007) also find links to improved productivity in manufacturing sectors from non-manufacturing regulatory reform, particularly with regards to reforms of trade regulations, and Arnold et al. (2010) find that barriers to foreign entry are likely to more be harmful for firms that are close to the frontier.

Nicoletti and Scarpetta (2003) provide additional evidence that suggests that countries and industries experiencing slow changes to their regulatory environment suffer from a technology gap in their ICT industries in particular.The difference in the timing in the technological boom in ICT technologies and the regulatory reform process in Europe is considered a key factor hindering effective accumulation of ICT capital, in particular in services industries, where deregulation has been much slower to take place (Arnold et al., 2008). Other studies also show that the detrimental effect of anti-competitive regulation on productivity over the 1990s was especially large in those sectors producing or using ICT intensively (Conway et al., 2006). This has largely been attributed to the fact that regulatory barriers to diffusion tend to be higher in these sectors compared to the rest of the economy; when there are rapid improvements in productivity the positive effects of pro-competitive regulations are amplified, increasing dispersion on productivity levels across countries with different regulatory regimes. Gains from market reform should therefore be higher in ICT-intensive sectors, where product market reform is found to have a direct impact on labour productivity growth. The existence of a long-run negative effect of an excessive regulation on multifactor productivity growth has been shown by Rincón-Aznar et al.(2009) for those sectors that use ICT intensively. Within the services sector, these sectors include wholesale and retail trade, financial intermediation and renting of machinery and equipment and business 
services ${ }^{4}$. These findings highlight the importance of exploring the sectoral differences between the EU and the US to have a better understanding of where the differences are concentrated.

\section{Labour Productivity}

\subsection{Trends in Sectoral Labour Productivity}

Recent evidence based on EUKLEMS has highlighted the fact that the slowdown in EU productivity growth hides a great deal of heterogeneity at the country and at the sectoral level (van Ark et al., 2008). Recent research on the EU-US productivity gap has concluded that the US has excelled in market services in general, and in retail and financial services in particular (Van Ark et al., 2007). The European Commission (2009) brings the debate to the present in a comprehensive review of recent evidence on competitiveness and growth in the light of the global economic downturn. Given that the economic climate has exacerbated problems of poor competitive performance in some sectors more than others, it is highlighted that the patterns of sectoral specialisation across countries have had an influence in the extent to which countries are exposed to recession.

The importance of the growth in service sectors has increased in the European Union between 1995 and 2007; there has been a considerable expansion in market services, which gained more than 4 percentage points to reach 49.2 per cent of total GDP in the EU (EC 2009). In contrast, the share of the manufacturing sector has decreased by 3.5 percentage points reflecting a change in industrial structure. However many European countries remain specialised in manufacturing industries as is the case of Germany, specialised in capital goods such as machinery and equipment, electrical and optical equipment and transport equipment.

The European Commission (2009) identifies five sectors as being strategically important for the European countries, in terms of interindustry linkages and spillovers for domestic and foreign economies. When looking at the domestic economy the sectors are: food products and beverages, construction work, manufacture of wood and products of wood and cork, articles of straw and plaiting materials, and recovered secondary materials. This highlights the heavy dependence on relatively low technology manufacturing sectors.The European Commission (2009) does highlight that in terms of internationally strategically important sectors, chemicals and office machinery and equipment are also important,

${ }^{4}$ See Inklaaret al. (2003), for a ICT taxonomy to classify industries on whether they are producers or users of ICT. 
suggesting pockets of higher technology performance. In contrast, services sectors such as wholesale and retail have more neutral effects throughout the economies despite their relatively large size.

Table 2 presents the average annual percentage growth in labour productivity measured in terms of gross value added per hour by broad economic sector.

Table 2 - LabourProductivity Growth by Aggregate Sector, 1995-2007*

\begin{tabular}{|c|c|c|c|c|c|c|c|}
\hline \multirow{2}{*}{$\begin{array}{l}\text { NACE NACE Description } \\
\text { Code }\end{array}$} & \multicolumn{4}{|c|}{$\begin{array}{l}\text { \% Growth in GVA per hour, } \\
1995-2007\end{array}$} & \multicolumn{3}{|c|}{$\begin{array}{l}\text { Difference with US LP } \\
\text { growth }\end{array}$} \\
\hline & NMS10* & EU15 & EU25 & US & NMS10* & EU15 & EU25 \\
\hline TOT Total industries & 3.54 & 1.42 & 1.70 & 1.93 & 1.61 & -0.51 & -0.23 \\
\hline AtB Agriculture, hunting, forestry and fishing & 3.10 & 2.71 & 2.57 & 4.52 & -1.42 & -1.81 & -1.95 \\
\hline C Mining and quarrying & 2.68 & 1.06 & 2.07 & -2.11 & 4.78 & 3.16 & 4.17 \\
\hline D Total manufacturing & 7.49 & 2.81 & 3.18 & 4.39 & 3.10 & -1.58 & -1.21 \\
\hline E Electricity, gas and water supply & 3.04 & 3.40 & 3.57 & 2.72 & 0.31 & 0.68 & 0.85 \\
\hline F Construction & 2.33 & -0.07 & 0.21 & -3.17 & 5.50 & 3.11 & 3.38 \\
\hline G Wholesale and retail trade & 4.65 & 1.79 & 2.05 & 3.79 & 0.87 & -2.00 & -1.74 \\
\hline H Hotels and restaurants & -1.51 & -0.08 & -0.09 & 0.68 & -2.19 & -0.76 & -0.76 \\
\hline I Transport, storage and communication & 4.08 & 3.58 & 3.75 & 3.32 & 0.76 & 0.26 & 0.44 \\
\hline J Financial intermediation & 6.76 & 3.32 & 3.51 & 2.91 & 3.85 & 0.42 & 0.60 \\
\hline K Real estate, renting and business activities & -1.68 & -0.97 & -1.00 & 1.37 & -3.05 & -2.34 & -2.37 \\
\hline $\begin{array}{l}\text { L Public administration and defence; } \\
\text { compulsory social security }\end{array}$ & 2.14 & 1.22 & 1.27 & 0.55 & 1.59 & 0.68 & 0.73 \\
\hline M Education & 2.03 & -0.72 & -0.17 & -0.59 & 2.62 & -0.13 & 0.43 \\
\hline N Health and social work & 2.44 & 0.72 & 0.95 & -0.12 & 2.56 & 0.84 & 1.07 \\
\hline $\begin{array}{l}\text { O Other community, social and personal } \\
\text { services }\end{array}$ & 1.44 & -0.29 & -0.06 & 1.90 & -0.47 & -2.19 & -1.96 \\
\hline P Private households with employed persons & -6.08 & -0.42 & -0.57 & 0.03 & -6.10 & -0.45 & -0.59 \\
\hline MSERV Market services $^{5}$ & 3.31 & 1.26 & 1.46 & 2.98 & 0.33 & -1.72 & -1.52 \\
\hline
\end{tabular}

*Growth calculations only to 2006 in NMS country grouping.

Source: EUKLEMS, November 2009 release. Own calculations.

Labour productivity growth in the NMS10 is over one percentage point higher than that of the US and more than 2 percentage points higher than that of the EU15. Note that a comparison between manufacturing and total market services (excluding post and telecommunications and real estate MServ) summarises the source of productivity differences between the US and Europe. Whilst there is some clear gap between US and EU productivity growth in manufacturing, there is less evidence of New Member States bolstering EU growth rates in the same way in market services. By sector, the EU15 exceeds US growth rates in mining and quarrying, electricity, gas and water supply, construction, transport,

${ }^{5}$ Note that the aggregate Market services excludes post and telecommunications and real estate activities. 
storage and communications. The EU15 surpasses the NMS10 growth rates only in electricity, gas and water supply, and labour productivity growth is less negative in hotels and real estate, renting and business activities in the EU15 than in NMS10. The NMS10 fared especially well in manufacturing, wholesale and retail trade, transport, storage and communications and financial intermediation.

Overall labour productivity growth rates in a number of industries do not differ vastly between the EU15 and the NMS10, particularly in primary industries such as agriculture and fishing. The industries in which the difference between these two groups are large include many of those industries listed above as being particularly fast growth sectors for the NMS10, for example manufacturing, wholesale and retail and financial intermediation. The figure for market services (excluding post and telecommunications) offers an interesting insight. We can see that that the average growth of the EU15 (1.46\%) was approximately half of the rate of the US $(2.98 \%)$ and less than half than the rate of the New Member States (3.31\%).

To consider the sectoral differences in productivity in greater detail, table 3 provides labour productivity growth figures for a further breakdown of sectors, as well as comparing the EU growth rates to the US. Within manufacturing, the largest productivity growth is seen in electrical and optical equipment (30t33) in all regions, although the growth in observed in the EU15 (where it accounts for the highest growth rates at around $6 \%$ ) is much lower than the growth observed in the US (around $15 \%$ ) and in the NMS10 (around 11\%).

In the EU15, other manufacturing sectors that experienced strong growth include chemicals, rubber and plastics and transport equipment (sectors 24-25 and 34t35) relatively high technology sectors. Earlier research suggests this is concentrated in the medical instruments sector specifically (Peneder, 2009). A negative average labour productivity growth is only seen in coke, refined petroleum and nuclear fuel (23). This sector experiences labour productivity decline throughout Europe, particularly in the NMS10 but steady growth in the US.

In comparison with the US, the EU15 growth is higher in around half of the manufacturing sectors, but these tend to be the lower technology sectors. Only in coke, refined petroleum and nuclear fuel and electrical and optical equipment (sectors 23 and 30t33) is growth faster in the US than in the NMS10. Overall, the stronger productivity growth in the NMS10 countries is a manifestation of catch-up with the rest of Europe; this is particularly marked in other non-metallic mineral products, machinery n.e.c, electrical and optical equipment and transport equipment (sectors 26, 29-35). 
Of the service sectors, only in post and telecommunications (64), does the EU15 exceed the US in labour productivity growth. In contrast, NMS10 shows higher labour productivity growth than the US in around half of the service sectors. It is growth in the sale, maintenance and repair of motor vehicles and the retail of fuel (50) where the US exceeds the NMS10. Labour productivity growth in wholesale trade (51) and retail trade (52) in the NMS10 is higher than growth observed in the US.

Table 3 - Average Labour Productivity Growth in Detailed Sectors, 1995-2007 (\%)

\begin{tabular}{|c|c|c|c|c|c|c|c|}
\hline \multirow{2}{*}{$\begin{array}{l}\text { NACE NACEDescription } \\
\text { Code }\end{array}$} & \multicolumn{4}{|c|}{$\begin{array}{l}\text { Average growth in labour } \\
\text { productivity, 1995-2007 }\end{array}$} & \multicolumn{3}{|c|}{ Difference with the US } \\
\hline & EU15 & EU25 & NMS10 & US & EU15 & EU25 & NMS10 \\
\hline 15t16 Food, beverages and tobacco & 0.96 & 1.67 & 6.12 & -0.53 & 1.49 & 2.19 & 6.64 \\
\hline 17t19 Textiles, leather and footwear & 1.93 & 2.42 & 4.82 & 3.37 & -1.44 & -0.95 & 1.45 \\
\hline 20 Wood and of wood and cork & 2.80 & 3.07 & 7.01 & 1.44 & 1.36 & 1.62 & 5.57 \\
\hline 21t22 Pulp, paper, printing and publishing & 2.33 & 2.38 & 5.33 & 1.32 & 1.01 & 1.06 & 4.02 \\
\hline 23 Coke, refined petroleum and nuclear fuel & -0.35 & -1.75 & -14.63 & 2.44 & -2.79 & -4.18 & -17.07 \\
\hline 24 Chemicals and chemical products & 3.85 & 4.18 & 6.81 & 4.50 & -0.66 & -0.32 & 2.30 \\
\hline 25 Rubber and plastics & 3.32 & 3.50 & 8.58 & 2.72 & 0.60 & 0.78 & 5.86 \\
\hline 26 Other non-metallic mineral products & 2.32 & 3.75 & 12.21 & 1.20 & 1.12 & 2.55 & 11.02 \\
\hline 27 t28 Basic and fabricated metals & 1.59 & 1.94 & 5.98 & 1.51 & 0.08 & 0.44 & 4.48 \\
\hline 29 Machinery, n.e.c. & 2.09 & 2.86 & 10.61 & 3.14 & -1.06 & -0.28 & 7.47 \\
\hline 30t33 Electrical and optical equipment & 6.04 & 5.94 & 11.25 & 15.12 & -9.08 & -9.18 & -3.87 \\
\hline 34t35 Transport equipment & 3.16 & 3.50 & 11.84 & 4.52 & -1.36 & -1.02 & 7.32 \\
\hline 36t37 Manufacturing n.e.c., recycling & 1.42 & 1.36 & 5.51 & 2.93 & -1.52 & -1.57 & 2.58 \\
\hline $\begin{array}{l}50 \text { Sale, maintenance and repair of motor } \\
\text { vehicles and motorcycles; retail sale of } \\
\text { fuel }\end{array}$ & 1.49 & 1.46 & 1.31 & 3.89 & -2.40 & -2.43 & -2.58 \\
\hline $\begin{array}{l}51 \text { Wholesale trade and commission trade, } \\
\text { except of motor vehicles and motorcycles }\end{array}$ & 2.28 & 2.59 & 6.21 & 5.03 & -2.75 & -2.44 & 1.18 \\
\hline $\begin{array}{l}52 \text { Retail trade, except of motor vehicles and } \\
\text { motorcycles; repair of household goods }\end{array}$ & 1.28 & 1.57 & 3.86 & 2.69 & -1.41 & -1.13 & 1.17 \\
\hline 60t63 Transport and storage & 1.96 & 2.22 & 3.27 & 1.99 & -0.03 & 0.23 & 1.28 \\
\hline 64 Post and telecommunications & 7.15 & 7.35 & 9.06 & 5.04 & 2.12 & 2.32 & 4.02 \\
\hline 70 Real estate activities & -0.51 & -0.48 & -0.71 & 0.73 & -1.24 & -1.21 & -1.44 \\
\hline $\begin{array}{l}\text { 71-74 Renting of machinery and equipment and } \\
\text { other business activities }\end{array}$ & 0.06 & 0.08 & 0.52 & 3.03 & -2.97 & -2.95 & -2.51 \\
\hline
\end{tabular}

*Growth calculations only to 2006 in NMS country grouping.

Source: EUKLEMS, November 2009 release. Own calculations. 


\subsection{Sectoral Contributions to Aggregate Labour Productivity Growth}

So far, we have looked at growth rates by sector, ignoring the relative contribution each sector makes to total productivity growth. Labour productivity growth rates must be weighted according to the size of the sector if we are to consider the importance of the growth rates to the aggregate growth. Table 4 contains the relative contributions of broad sectors, calculated as the total labour productivity growth in these sectors weighted by their share in total hours worked. In table 4 we see that the difference in total average labour productivity growth for the period 19952007 between the US (1.93\%) and the EU25 (1.70\%) is 0.23 percentage points. This difference is lower than the one observed in the period 19952004 (Penederet al., 2009), which is in part an indication that over the last years of the sample the EU has reduced the differences in aggregate growth with respect to the US. Despite this the sectoral differences remain substantial.

Manufacturing accounts for 32 per cent of total labour productivity growth in the United States and around 34 per cent in the EU15, whilst this is almost 47 per cent in the New Member States. Wholesale and retail trade make the second most important contribution in all regions, although this is clearly higher in the US. A telling finding is that market services (excluding post and telecommunications and real estate) contribute over 70 per cent to the total labour productivity growth in the US, whilst this is only around 30 to 40 cent in the EU. The sectors that have had a negative contribution to total labour productivity include construction, real estate activities ${ }^{6}$ and other community, social and personal services in the EU15 and construction in the US. Finally, the reallocation of labour between sectors within the economy has an important positive impact on the US and EU15average labour productivity. It is slightly higher in the US, whilst the contribution of this effect to labour productivity growth is negative in the NMS10.

Table 4 - Contributions to Total LP Growth by Sector, 1995-2007

\begin{tabular}{|c|c|c|c|c|}
\hline \multirow{2}{*}{$\begin{array}{l}\text { NACE } \\
\text { Code }\end{array}$} & \multicolumn{4}{|c|}{ Contributions to total LP growth by sector } \\
\hline & NMS10 & EU15 & EU25 & US \\
\hline TOT Total industries & 3.54 & 1.42 & 1.70 & 1.93 \\
\hline AtB Agriculture, hunting, forestry and fishing & 0.44 & 0.15 & 0.18 & 0.09 \\
\hline C Mining and quarrying & 0.04 & 0.00 & 0.01 & -0.01 \\
\hline D Total manufacturing & 1.65 & 0.49 & 0.58 & 0.63 \\
\hline 15t16 Food, beverages and tobacco & 0.22 & 0.02 & 0.04 & -0.01 \\
\hline
\end{tabular}

\footnotetext{
${ }^{6}$ We caution against placing too much emphasis on the Real Estate (70) productivity measure given the problems of inclusion of owner occupied rents
} 
Table 4 - Continued

\begin{tabular}{|c|c|c|c|c|}
\hline \multirow{2}{*}{$\begin{array}{l}\text { NACE } \\
\text { Code }\end{array}$} & \multicolumn{4}{|c|}{ Contributions to total LP growth by sector } \\
\hline & NMS10 & EU15 & EU25 & US \\
\hline 17t19 Textiles, leather and footwear & 0.15 & 0.03 & 0.04 & 0.03 \\
\hline 20 Wood and of wood and cork & 0.09 & 0.02 & 0.02 & 0.01 \\
\hline 21t22 Pulp, paper, printing and publishing & 0.06 & 0.03 & 0.03 & 0.02 \\
\hline 23 Coke, refined petroleum and nuclear fuel & -0.02 & 0.00 & 0.00 & 0.00 \\
\hline 24 Chemicals and chemical products & 0.06 & 0.04 & 0.04 & 0.04 \\
\hline 25 Rubber and plastics & 0.08 & 0.03 & 0.03 & 0.02 \\
\hline 26 Other non-metallic mineral products & 0.14 & 0.02 & 0.03 & 0.01 \\
\hline 27t28 Basic and fabricated metals & 0.17 & 0.04 & 0.05 & 0.03 \\
\hline 29 Machinery, n.e.c. & 0.20 & 0.04 & 0.05 & 0.03 \\
\hline 30t33 Electrical and optical equipment & 0.24 & 0.11 & 0.11 & 0.30 \\
\hline 34t35 Transport equipment & 0.16 & 0.05 & 0.05 & 0.07 \\
\hline 36t37 Manufacturing n.e.c., recycling & 0.08 & 0.02 & 0.02 & 0.03 \\
\hline E Electricity, gas and water supply & 0.05 & 0.02 & 0.03 & 0.01 \\
\hline F Construction & 0.16 & -0.01 & 0.02 & -0.22 \\
\hline $\begin{array}{l}50 \text { Sale, maintenance and repair of motor vehicles and } \\
\text { motorcycles; retail sale of fuel }\end{array}$ & 0.03 & 0.04 & 0.03 & 0.12 \\
\hline $\begin{array}{l}51 \text { Wholesale trade and commission trade, except of motor } \\
\text { vehicles and motorcycles }\end{array}$ & 0.31 & 0.11 & 0.13 & 0.22 \\
\hline $\begin{array}{l}52 \text { Retail trade, except of motor vehicles and motorcycles; } \\
\text { repair of household goods }\end{array}$ & 0.34 & 0.11 & 0.13 & 0.23 \\
\hline $\mathrm{H}$ Hotels and Restaurants & -0.04 & 0.00 & 0.00 & 0.04 \\
\hline 60t63 Transport and storage & 0.17 & 0.10 & 0.11 & 0.06 \\
\hline 64 Post and telecommunications & 0.13 & 0.10 & 0.11 & 0.09 \\
\hline J Financial Intermediation & 0.13 & 0.10 & 0.10 & 0.13 \\
\hline 70 Real estate activities & -0.01 & -0.01 & 0.00 & 0.01 \\
\hline 71t74 Renting of m\&eq and other business activities & 0.03 & 0.01 & 0.01 & 0.37 \\
\hline $\begin{array}{l}\text { L Public administration and defence; compulsory social } \\
\text { security }\end{array}$ & 0.12 & 0.08 & 0.08 & 0.05 \\
\hline M Education & 0.11 & -0.04 & -0.01 & -0.05 \\
\hline $\mathrm{N}$ Health and social work & 0.14 & 0.06 & 0.07 & -0.01 \\
\hline O Other community, social and personal services & 0.05 & -0.01 & 0.00 & 0.10 \\
\hline P Private households with employed persons & -0.01 & -0.01 & -0.01 & 0.00 \\
\hline MSERV MarketServices & 1.12 & 0.57 & 0.64 & 1.40 \\
\hline Reallocation of labour & -0.32 & 0.12 & 0.13 & 0.05 \\
\hline
\end{tabular}

Note: The average for the NMS10 is for the period 1995-2006.

Source: EUKLEMS, November 2009 release. Own calculations.

Figure 1 shows graphically which sectors are driving the difference in total labour productivity growth. From left to right we have arranged the sectors according to their contribution to the US-EU productivity gap, in decreasing order. Those sectors where the contribution to total growth is higher in the US than in the EU are shown in the left hand side of the graph. The sectors for which the contribution is largest in the US than in the EU include renting of machinery and equipment and other business services, wholesale and retail trade and electrical and optical equipment. If we add the contribution of other market services such as hotels and restaurants, other community, social and personal services and financial 
intermediation, the difference in total labour productivity growth between the US and the EU is 1 percentage point.

On the right hand side of Figure 1, we have those sectors which help reduce the labour productivity gap between the US and the EU25. Construction, agriculture, hunting, forestry and fishing, health and food, drink and tobacco and the effect of labour reallocation across sectors show a relative higher contribution to growth in the EU than in the US thus narrowing the productivity gap. We observe that the slope on the left hand side of the graph is much steeper, suggesting that the productivity gap is driven by a few sectors. Off-setting this effect, in the right hand side of the graph we observe a number of non-market service sectors such as health, public administration and education. However we do not place much emphasis on this finding, as any direct comparisons between Europe and the US in these sectors is bound to be problematic.

Figure 1 - Contributions by Sector to Gap in LP Growth Between the EU25 and the US, 1995-2007

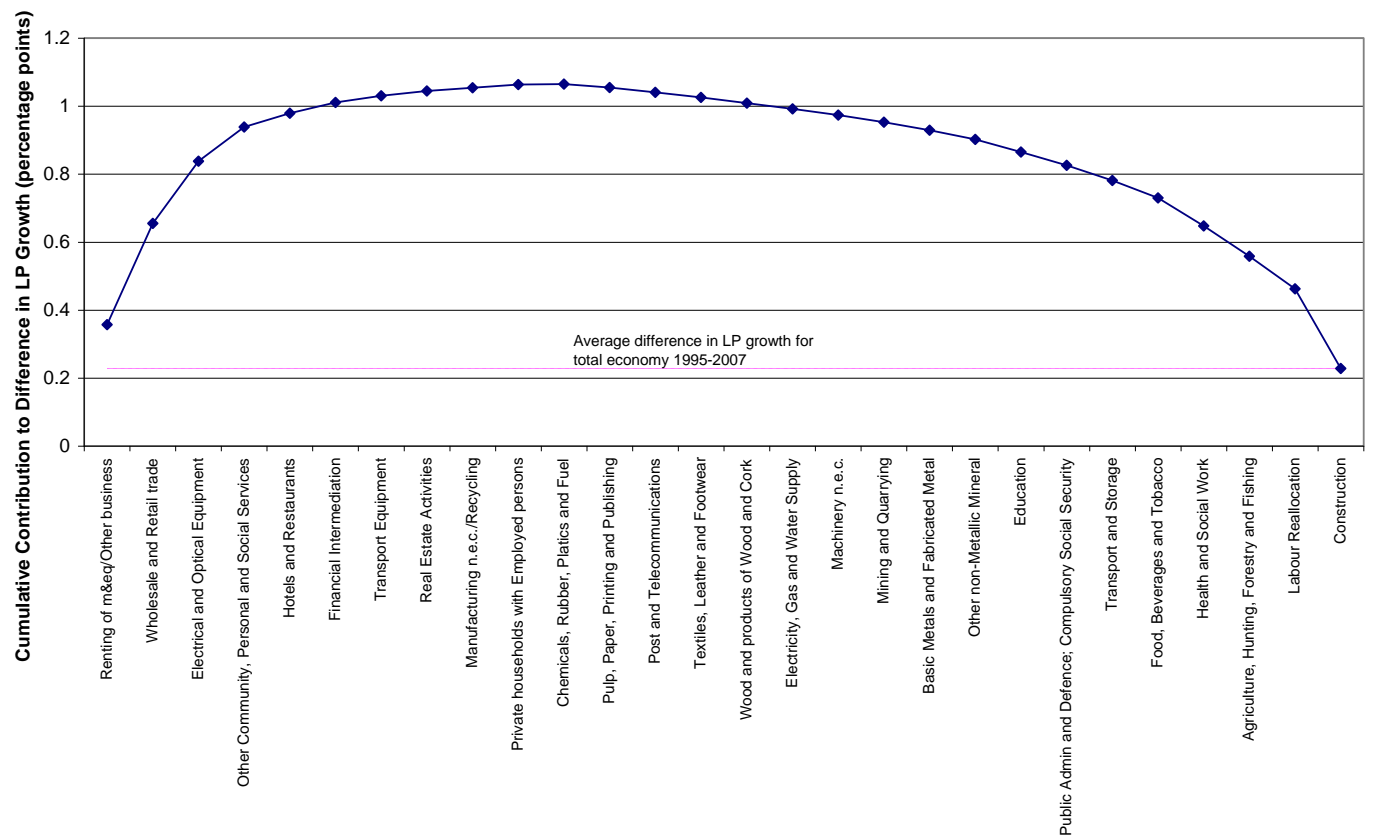

Source: EUKLEMS, November 2009 release. Own calculations.

\section{Multifactor Productivity}

\subsection{Trends in Multifactor Productivity by Sector}

To gain a more holistic view of productivity growth, we present average MFP growth rates for the period 1995-2007 for manufacturing and 
services respectively (tables 5 and 6). Annual MFP growth rates have been calculated for the EU-15ex ${ }^{7}$ aggregate and the US by industry.

Within the EU manufacturing we observe negative MFP growth in food and the manufacture of coke and fuel; these are traditional, lowtechnology industries largely in the mature stage of their product life cycle. The US shows high MFP growth rates in some traditional sectors mainly textiles, leather and footwear and pulp, paper and paper products.

The highest rates of MFP growth are seen in the electrical and optical equipment sector in both the EU and the US, although US growth outstrips the EU by a factor of 3. In comparison with the US MFP growth is high in the EU-15ex in wood products, rubber and plastics and other non-metallic mineral products. With the exception perhaps of rubber and plastics, these are generally regarded as relatively low technology sectors. Research using previous versions of EU KLEMS data suggested that chemicals also performed well in the EU compared with the US, however, this story does not hold as we extend the analysis into the latter half of the decade (Rincón-Aznar et al., Chapter 2, in Penederet al., 2008).

Table 5 - MFP Growth in the Manufacturing Sector for 1995-2007, EU-15ex

\begin{tabular}{|c|c|c|c|c|c|c|}
\hline \multirow[b]{2}{*}{$\begin{array}{l}\text { NACE } \\
\text { Code }\end{array}$} & \multicolumn{3}{|c|}{ \%MFP growth } & \multicolumn{3}{|c|}{ \%LP growth } \\
\hline & $\begin{array}{c}\text { EU- } \\
15 e x\end{array}$ & US & $\begin{array}{l}\text { EU-15ex } \\
\text { difference } \\
\text { to US }\end{array}$ & EU10 & US & $\begin{array}{c}\text { EU-15ex } \\
\text { difference } \\
\text { to US }\end{array}$ \\
\hline D Total manufacturing & 1.47 & 2.66 & -1.19 & 2.60 & 4.39 & -1.79 \\
\hline 15t16 Food, beverages and tobacco & -0.03 & -1.24 & 1.21 & 0.83 & -0.53 & 1.35 \\
\hline 17t19 Textiles, leather and footwear & 0.87 & 1.25 & -0.37 & 2.25 & 3.37 & -1.12 \\
\hline 20 Wood and products of wood and cork & 1.66 & 0.66 & 1.00 & 2.64 & 1.44 & 1.20 \\
\hline 21t22 Pulp, paper, printing and publishing & 0.57 & -0.05 & 0.62 & 2.00 & 1.32 & 0.69 \\
\hline 23 t25 Chemicals, rubber, plastics and fuel & 1.67 & 1.10 & 0.57 & 2.95 & 3.49 & -0.54 \\
\hline 23 Coke, refined petroleum and nuclear fuel & -2.99 & -0.51 & -2.49 & -1.19 & 2.44 & -3.63 \\
\hline 24 Chemicals and chemical products & 2.04 & 2.02 & 0.02 & 3.56 & 4.50 & -0.94 \\
\hline 25 Rubber and plastics & 2.21 & 0.97 & 1.25 & 3.34 & 2.72 & 0.62 \\
\hline 26 Other non-metallic mineral products & 1.07 & 0.01 & 1.07 & 2.34 & 1.20 & 1.14 \\
\hline 27t28 Basic and fabricated metals & 0.87 & 0.91 & -0.04 & 1.55 & 1.51 & 0.04 \\
\hline 29 Machinery n.e.c. & 1.38 & 0.66 & 0.73 & 2.04 & 3.14 & -1.11 \\
\hline 30t33 Electrical and optical equipment & 4.01 & 12.99 & -8.97 & 5.38 & 15.12 & -9.73 \\
\hline 34t35 Transport equipment & 2.07 & 3.00 & -0.93 & 3.05 & 4.52 & -1.48 \\
\hline 36t37 Manufacturing n.e.c., recycling & 0.47 & 1.58 & -1.11 & 1.31 & 2.93 & -1.62 \\
\hline
\end{tabular}

Note: The average for the NMS10 is for the period 1995-2006.

Source: EUKLEMS, November 2009 release. Own calculations.

${ }^{7}$ These are countries for which full growth accounts are available in the EU KLEMS and consist of Austria, Belgium, Denmark, Spain, Finland, France, Germany, Italy, Netherlands and the UK. This is broadly similar to the EU15, but excludes Ireland, Luxembourg, Sweden, Portugal and Greece for which information on capital input was not available. 
In the service sectors (table 6) negative MFP growth is seen in a number of non-manufacturing sectors in the EU. This is the case of the construction sector to a small degree, hotels and restaurants, and more substantially, renting of machinery and equipment and business services. With the exception of construction, real estate and non-market services (education and health) the US has experienced positive MFP growth.

The EU-15ex shows positive and higher MFP growth than the US in the transport and storage, post and telecommunications and financial intermediation sectors. Sectors where the US significantly outperform the EU-15ex include the wholesale and retail sectors and also other community, social and personal services. If we compare market services as a whole we observe that MFP growth in the US (1.30\%) to be much higher than the growth observed in the EU-15ex (0.04\%).

Table 6 - MFP Growth in the Service Sector for 1995-2007, EU-15ex

\begin{tabular}{|c|c|c|c|c|c|c|}
\hline \multirow[b]{2}{*}{$\begin{array}{l}\text { NACE NACE Description } \\
\text { Code }\end{array}$} & \multicolumn{3}{|c|}{ \%MFP growth } & \multicolumn{3}{|c|}{ \%LP growth } \\
\hline & $\begin{array}{l}\text { EU- } \\
15 e x\end{array}$ & US & $\begin{array}{l}\text { Diff. } \\
\text { to US }\end{array}$ & $\begin{array}{l}\text { EU- } \\
15 e x\end{array}$ & US & $\begin{array}{l}\text { Diff. } \\
\text { to US }\end{array}$ \\
\hline F Construction & -0.71 & -3.77 & 3.06 & -0.04 & -3.17 & 3.13 \\
\hline $\begin{array}{l}50 \text { Sale, maintenance and repair of motor } \\
\text { vehicles and motorcycles; retail sale of fuel }\end{array}$ & 0.27 & 2.72 & -2.44 & 1.49 & 3.89 & -2.40 \\
\hline $\begin{array}{l}51 \text { Wholesale trade and commission trade, } \\
\text { except of motor vehicles and motorcycles }\end{array}$ & 1.18 & 3.20 & -2.02 & 2.29 & 5.03 & -2.74 \\
\hline $\begin{array}{l}52 \text { Retail trade, except of motor vehicles and } \\
\text { motorcycles; repair of household goods }\end{array}$ & 0.41 & 1.83 & -1.42 & 1.21 & 2.69 & -1.48 \\
\hline $\mathrm{H}$ Hotels and restaurants & -0.86 & 0.20 & -1.07 & -0.09 & 0.68 & -0.77 \\
\hline I Transport, storage and communications & 2.16 & 1.46 & 0.70 & 3.56 & 3.32 & 0.24 \\
\hline 60t63 Transport and storage & 0.86 & 0.87 & -0.01 & 1.91 & 1.99 & -0.08 \\
\hline 64 Post and telecommunications & 4.65 & 2.02 & 2.63 & 7.25 & 5.04 & 2.21 \\
\hline J Financial intermediation & 1.59 & 0.61 & 0.98 & 3.11 & 2.91 & 0.20 \\
\hline 70 Real estate activities & -0.34 & -0.22 & -0.12 & -0.56 & 0.73 & -1.29 \\
\hline $\begin{array}{l}\text { 71t74 Renting of m\&eq and other business } \\
\text { activities }\end{array}$ & -1.25 & 0.65 & -1.91 & 0.04 & 3.03 & -2.99 \\
\hline $\begin{array}{l}\text { L Public Administration and defence; } \\
\text { compulsory social security }\end{array}$ & 0.49 & -0.58 & 1.07 & 1.32 & 0.55 & 0.77 \\
\hline M Education & -1.20 & -1.44 & 0.24 & -0.75 & -0.59 & -0.15 \\
\hline $\mathrm{N}$ Health and social work & 0.10 & -1.01 & 1.11 & 0.75 & -0.12 & 0.87 \\
\hline $\begin{array}{l}\text { O Other community, social and personal } \\
\text { services }\end{array}$ & -1.01 & 1.36 & -2.37 & -0.45 & 1.90 & -2.35 \\
\hline MSERV Marketservices & 0.04 & 1.30 & -1.26 & 1.17 & 2.97 & -1.80 \\
\hline
\end{tabular}

Source: EUKLEMS, November 2009 release. Own calculations.

\subsection{The Contribution of MFP to Value Added Growth}

The characteristics of the sectors in terms of the various production factors are considered essential to understand sectoral performance. In this section we explore the role played by factor accumulation and 
multifactor productivity growth in explaining differences in output growth in both the EU and US.

Tables 7 and 8 show the average contribution that capital (ICT-capital and non-ICT capital) ${ }^{8}$, labour (hours and labour composition ${ }^{9}$ ) and MFP make to total value added growth for the period 1995-2007. These figures are available for the EU-15ex aggregate and the US.

Table 7 - Gross Value Added Growth and Contributions for the EU-15ex, 1995-2007 (value added growth is average annual growth rate in \%)

\begin{tabular}{|c|c|c|c|c|c|c|}
\hline \multirow[b]{2}{*}{ NACE Description } & \multirow[b]{2}{*}{$\begin{array}{c}\text { Value } \\
\text { added } \\
\text { growth }\end{array}$} & \multicolumn{2}{|c|}{ LABOUR } & \multicolumn{2}{|c|}{ CAPITAL } & \multirow[b]{2}{*}{ MFP } \\
\hline & & Hours & $\begin{array}{r}\text { Labour } \\
\text { Compo- } \\
\text { sition }\end{array}$ & $\begin{array}{r}\text { ICT } \\
\text { Capital }\end{array}$ & $\begin{array}{r}\text { non-ICT } \\
\text { Capital }\end{array}$ & \\
\hline TOT Total industries & 2.22 & 0.58 & 0.16 & 0.44 & 0.69 & 0.36 \\
\hline $\begin{array}{l}\text { AtB Agriculture, hunting, forestry and } \\
\text { fishing }\end{array}$ & 0.69 & -1.55 & 0.23 & 0.02 & 0.18 & 1.80 \\
\hline C Mining and quarrying & -2.38 & -1.15 & 0.02 & 0.11 & 0.40 & -1.75 \\
\hline D Total manufacturing & 1.56 & -0.74 & 0.29 & 0.29 & 0.26 & 1.47 \\
\hline 15 t16 Food, beverages and tobacco & 0.27 & -0.38 & 0.32 & 0.20 & 0.15 & -0.03 \\
\hline 17t19 Textiles, leather and footwear & -2.44 & -3.54 & 0.21 & 0.15 & -0.13 & 0.87 \\
\hline 20 Wood and products of wood and cork & 1.00 & -1.26 & 0.09 & 0.17 & 0.34 & 1.66 \\
\hline 21t22 Pulp, paper, printing and publishing & 0.61 & -0.95 & 0.22 & 0.48 & 0.29 & 0.57 \\
\hline 23t25 Chemicals, rubber, plastics and fuel & 1.95 & -0.61 & 0.17 & 0.28 & 0.44 & 1.67 \\
\hline $\begin{array}{l}23 \text { Coke, refined petroleum and nuclear } \\
\text { fuel }\end{array}$ & -2.94 & -0.75 & 0.06 & 0.29 & 0.44 & -2.99 \\
\hline 24 Chemicals and chemical products & 2.18 & -0.81 & 0.22 & 0.30 & 0.44 & 2.04 \\
\hline 25 Rubber and plastics & 2.87 & -0.35 & 0.31 & 0.24 & 0.46 & 2.21 \\
\hline 26 Other non-metallic mineral & 1.02 & -0.89 & 0.24 & 0.19 & 0.41 & 1.07 \\
\hline $27 t 28$ Basic metals and fabricated metals & 1.54 & -0.02 & 0.26 & 0.18 & 0.25 & 0.87 \\
\hline 29 Machinery n.e.c. & 1.78 & -0.20 & 0.19 & 0.27 & 0.14 & 1.38 \\
\hline 30t33 Electrical and optical equipment & 4.03 & -1.04 & 0.23 & 0.55 & 0.29 & 4.01 \\
\hline 34t35 Transport equipment & 2.74 & -0.22 & 0.28 & 0.24 & 0.37 & 2.07 \\
\hline 36t37 Manufacturing n.e.c, recycling & 0.41 & -0.70 & 0.20 & 0.25 & 0.20 & 0.47 \\
\hline E Electricity, gas and water supply & 1.90 & -0.62 & 0.05 & 0.27 & 0.67 & 1.53 \\
\hline F Construction & 1.31 & 1.04 & 0.14 & 0.13 & 0.71 & -0.71 \\
\hline
\end{tabular}

Table continues on next page

${ }^{8}$ We divide capital input growth into two groups of assets: ICT and non-ICT assets, such that:

$\Delta \ln K_{j t}=\bar{w}_{j t}^{I C T} \Delta \ln K_{j t}^{I C T}+\bar{w}_{j t}^{N} \Delta \ln K_{j t}^{N}$

with $\bar{w}_{j t}^{I C T}$ the period-average share of ICT assets in total capital costs in industry $j$ at $t$, and similarly for non-ICT assets.

${ }^{9}$ The volume growth of labour input was split into the growth of hours worked and the changes in labour composition in terms of labour characteristics such as educational attainment, age or gender. 
Table 7 - Continued

\begin{tabular}{|c|c|c|c|c|c|c|}
\hline \multirow[b]{2}{*}{ NACE Description } & \multirow[b]{2}{*}{$\begin{array}{l}\text { Value } \\
\text { added } \\
\text { growth }\end{array}$} & \multicolumn{2}{|c|}{ LABOUR } & \multicolumn{2}{|c|}{ CAPITAL } & \multirow[b]{2}{*}{ MFP } \\
\hline & & Hours & $\begin{array}{r}\text { Labour } \\
\text { Compo- } \\
\text { sition }\end{array}$ & $\begin{array}{r}\text { ICT } \\
\text { Capital }\end{array}$ & $\begin{array}{r}\text { non-ICT } \\
\text { Capital }\end{array}$ & \\
\hline G Wholesale and retail trade & 2.33 & 0.42 & 0.13 & 0.43 & 0.62 & 0.72 \\
\hline $\begin{array}{l}50 \text { Sale, maintenance and repair of motor } \\
\text { vehicles and motorcycles; retail sale of } \\
\text { fuel }\end{array}$ & 2.33 & 0.62 & 0.30 & 0.35 & 0.78 & 0.27 \\
\hline $\begin{array}{l}51 \text { Wholesale trade and commission } \\
\text { trade, except of motor vehicles and } \\
\text { motorcycles }\end{array}$ & 2.98 & 0.46 & 0.01 & 0.62 & 0.71 & 1.18 \\
\hline $\begin{array}{l}52 \text { Retail trade, except of motor vehicles } \\
\text { and motorcycles; repair of household } \\
\text { goods }\end{array}$ & 1.60 & 0.33 & 0.15 & 0.25 & 0.46 & 0.41 \\
\hline $\mathrm{H}$ Hotels and restaurants & 1.88 & 1.63 & 0.22 & 0.14 & 0.76 & -0.86 \\
\hline $\begin{array}{l}\text { I Transport and storage and } \\
\text { communications }\end{array}$ & 4.35 & 0.53 & 0.10 & 0.88 & 0.69 & 2.16 \\
\hline 60t63 Transport and storage & 3.03 & 0.82 & 0.14 & 0.46 & 0.75 & 0.86 \\
\hline 64 Post and telecommunications & 6.92 & -0.17 & 0.18 & 1.71 & 0.56 & 4.65 \\
\hline $\begin{array}{l}\text { JtK Finance, insurance, real estate and } \\
\text { business activities }\end{array}$ & 3.13 & 1.37 & 0.02 & 0.72 & 1.30 & -0.28 \\
\hline J Financial intermediation & 3.34 & 0.14 & 0.35 & 1.14 & 0.13 & 1.59 \\
\hline $\begin{array}{l}\text { K Real estate, renting and business } \\
\text { activities }\end{array}$ & 3.06 & 1.46 & 0.15 & 0.61 & 1.59 & -0.76 \\
\hline 70 Real estate activities & 1.96 & 0.18 & 0.04 & 0.08 & 1.99 & -0.34 \\
\hline $\begin{array}{l}\text { 71t74 Renting of m\&eq and other business } \\
\text { activities }\end{array}$ & 4.21 & 2.81 & 0.27 & 1.18 & 1.21 & -1.25 \\
\hline $\begin{array}{l}\text { LtQ Community, social and personal } \\
\text { services }\end{array}$ & 1.50 & 1.06 & 0.11 & 0.25 & 0.34 & -0.27 \\
\hline $\begin{array}{l}\text { L Public administration and defence; } \\
\text { compulsory social security }\end{array}$ & 0.97 & -0.29 & 0.24 & 0.30 & 0.23 & 0.49 \\
\hline M Education & 0.72 & 1.39 & 0.29 & 0.16 & 0.08 & -1.20 \\
\hline $\mathrm{N}$ Health and social work & 2.55 & 1.48 & 0.26 & 0.23 & 0.48 & 0.10 \\
\hline $\begin{array}{l}\text { O Other community, social and personal } \\
\text { services }\end{array}$ & 1.60 & 1.48 & 0.03 & 0.39 & 0.71 & -1.01 \\
\hline MSERV Market services & 2.95 & 1.25 & 0.20 & 0.71 & 0.74 & 0.05 \\
\hline
\end{tabular}

Source: EUKLEMS, November 2009 release. Own calculations.

We observe that for the aggregate US economy MFP contributes 20 per cent to the total value added growth, compared to 16 per cent in the EU. If we look at market services the difference is more striking. Whilst in the US MFP growth contributes in a 25 per cent to total value added growth in the EU-15 this is less than 2 per cent. The contribution of ICT capital in both regions is comparable, around 20-25 per cent, whilst the contribution of employment is larger in the EU and the contribution of labour quality is higher in the US. 
Table 8 - Gross Value Added Growth and Contributions for the US, 1995-2007 (value added growth is average annual growth rate in \%)

\begin{tabular}{|c|c|c|c|c|c|c|}
\hline \multirow[b]{2}{*}{$\begin{array}{l}\text { NACE NACE Description } \\
\text { Code }\end{array}$} & \multirow[b]{2}{*}{$\begin{array}{l}\text { Value } \\
\text { added } \\
\text { growth }\end{array}$} & \multicolumn{2}{|c|}{ LABOUR } & \multicolumn{2}{|c|}{ CAPITAL } & \multirow[b]{2}{*}{ MFP } \\
\hline & & Hours & $\begin{array}{c}\text { Labour } \\
\text { Compo- } \\
\text { sition } \\
\end{array}$ & $\begin{array}{r}\text { ICT } \\
\text { Capital }\end{array}$ & $\begin{array}{r}\text { non-ICT } \\
\text { Capital }\end{array}$ & \\
\hline TOT Total industries & 3.02 & 0.70 & 0.21 & 0.75 & 0.77 & 0.59 \\
\hline AtB Agriculture, hunting, forestry and fishing & 4.49 & 0.02 & 0.11 & 0.12 & 0.64 & 3.60 \\
\hline C Mining and quarrying & -1.51 & -0.04 & -0.11 & 0.44 & 1.17 & -2.97 \\
\hline D Total manufacturing & 2.40 & -1.33 & 0.35 & 0.55 & 0.18 & 2.66 \\
\hline 15 t16 Food, beverages and tobacco & -1.02 & -0.29 & 0.26 & 0.42 & -0.17 & -1.24 \\
\hline 17t19 Textiles, leather and footwear & -4.24 & -5.72 & 0.61 & 0.14 & -0.51 & 1.25 \\
\hline 20 Wood and products of wood and cork & 0.18 & -0.95 & 0.21 & 0.20 & 0.06 & 0.66 \\
\hline 21t22 Pulp, paper, printing and publishing & -0.96 & -1.48 & 0.27 & 0.58 & -0.28 & -0.05 \\
\hline 23t25 Chemicals, rubber, plastics and fuel & 1.39 & -1.00 & 0.20 & 0.71 & 0.38 & 1.10 \\
\hline 23 Coke, refined petroleum and nuclear fuel & -0.20 & -0.96 & 0.14 & 0.84 & 0.29 & -0.51 \\
\hline 24 Chemicals and chemical products & 2.27 & -1.03 & 0.21 & 0.82 & 0.25 & 2.02 \\
\hline 25 Rubber and plastics & 0.87 & -1.14 & 0.28 & 0.25 & 0.52 & 0.97 \\
\hline 26 Other non-metallic mineral & 0.86 & -0.20 & 0.24 & 0.42 & 0.39 & 0.01 \\
\hline 27t28 Basic metals and fabricated metals & 0.42 & -0.81 & 0.23 & 0.28 & -0.19 & 0.91 \\
\hline 29 Machinery n.e.c. & 1.15 & -1.49 & 0.43 & 0.94 & 0.61 & 0.66 \\
\hline 30t33 Electrical and optical equipment & 12.49 & -2.21 & 0.61 & 0.61 & 0.49 & 12.99 \\
\hline 34t35 Transport equipment & 2.91 & -1.21 & 0.27 & 0.53 & 0.32 & 3.00 \\
\hline 36t37 Manufacturing n.e.c, recycling & 1.87 & -0.84 & 0.48 & 0.43 & 0.22 & 1.58 \\
\hline E Electricity, gas and water supply & 1.15 & -0.39 & 0.10 & 0.55 & 0.73 & 0.16 \\
\hline F Construction & -0.48 & 2.34 & 0.06 & 0.41 & 0.48 & -3.77 \\
\hline G Wholesale and retail trade & 4.33 & 0.40 & 0.24 & 0.68 & 0.50 & 2.51 \\
\hline $\begin{array}{l}50 \text { Sale, maintenance and repair of motor } \\
\text { vehicles and motorcycles; retail sale of fuel }\end{array}$ & 3.92 & 0.04 & 0.17 & 0.51 & 0.47 & 2.72 \\
\hline $\begin{array}{l}51 \text { Wholesale trade and commission trade, } \\
\text { except of motor vehicles and motorcycles }\end{array}$ & 5.51 & 0.33 & 0.27 & 1.07 & 0.64 & 3.20 \\
\hline $\begin{array}{l}52 \text { Retail trade, except of motor vehicles and } \\
\text { motorcycles; repair of household goods }\end{array}$ & 3.46 & 0.59 & 0.26 & 0.39 & 0.38 & 1.83 \\
\hline $\mathrm{H}$ Hotels and restaurants & 2.72 & 1.48 & 0.23 & 0.19 & 0.62 & 0.20 \\
\hline I Transport and storage and communications & 3.98 & 0.40 & 0.07 & 1.72 & 0.34 & 1.46 \\
\hline 60t63 Transport and storage & 3.19 & 0.86 & 0.20 & 1.15 & 0.12 & 0.87 \\
\hline 64 Post and telecommunications & 4.72 & -0.16 & 0.09 & 2.23 & 0.54 & 2.02 \\
\hline $\begin{array}{l}\text { JtK Finance, insurance, real estate and business } \\
\text { activities }\end{array}$ & 4.30 & 1.14 & 0.22 & 1.14 & 1.48 & 0.32 \\
\hline J Financial intermediation & 4.33 & 0.79 & 0.35 & 1.75 & 0.83 & 0.61 \\
\hline K Real estate, renting and business activities & 4.29 & 1.20 & 0.25 & 0.92 & 1.72 & 0.21 \\
\hline 70 Real estate activities & 2.63 & 0.12 & 0.02 & 0.07 & 2.63 & -0.22 \\
\hline $\begin{array}{l}\text { 71t74 Renting of m\&eq and other business } \\
\text { activities }\end{array}$ & 6.06 & 2.37 & 0.45 & 1.83 & 0.76 & 0.65 \\
\hline LtQ Community, social and personal services & 1.81 & 1.35 & 0.21 & 0.34 & 0.50 & -0.59 \\
\hline $\begin{array}{l}\text { L Public administration and defence; } \\
\text { compulsory social security }\end{array}$ & 0.93 & 0.32 & 0.23 & 0.38 & 0.59 & -0.58 \\
\hline M Education & 1.31 & 1.73 & 0.28 & 0.43 & 0.31 & -1.44 \\
\hline $\mathrm{N}$ Health and social work & 2.35 & 2.13 & 0.34 & 0.30 & 0.58 & -1.01 \\
\hline $\begin{array}{l}\text { O Other community, social and personal } \\
\text { services }\end{array}$ & 3.38 & 1.17 & 0.27 & 0.21 & 0.37 & 1.36 \\
\hline MSERV Market services & 4.47 & 1.25 & 0.32 & 1.16 & 0.62 & 1.12 \\
\hline
\end{tabular}

Source: EUKLEMS, November 2009 release. Own calculations. 
Tables 7 and 8 reveal other interesting differences across sectors between the EU and the US. The sectors in which MFP contributes in the highest proportion to value added growth in the EU are agriculture and wood products, sectors where inputs to production (capital and labour) have a negative impact on value added growth. In the US, MFP growth is largest in wood products, textiles, chemicals, and machinery n.e.c.

Other industries that experience high MFP growth include electrical and optical equipment (30t33), wholesale and retail and sale and repair of motor vehicles (50-52) and the financial intermediation sector where MFP accounts for over 50 per cent of total value added growth. The contribution of inputs to production in the wholesale and retail sector is more important than the contribution of multifactor productivity in the EU; this is also true for the financial intermediation sector. In contrast in traditional manufacturing sectors such as textiles, leather and footwear, wood and wood products and pulp, paper and paper products, the US is experiencing larger negative contributions of inputs in comparison to the EU. This is likely to be due to downsizing in these sectors. In general increases in productivity in the manufacturing sector have not been accompanied by increases in employment. The US has been moving resources more rapidly out of these sectors than the EU -another important factor in accounting for productivity differentials. The speed with which industries/firms can respond to the need to reallocate resources depends on the regulatory framework in which they operate, and in this respect some considerable progress has been made in the EU in recent years, although faster in some countries than in others.

Overall we note a wide variation across sectors in the contribution of the different factors of production in both the US and EU. In general MFP represents a large part of the growth in some high technology sectors, such as post and telecommunications but it is also relevant in declining industries such as traditional manufacturing, agriculture and mining, particularly in the US. In market service sectors the relative contribution of MFP is higher in the US than in the EU, while in other production and network industries such as agriculture, electricity, gas and water, transport and storage and post and telecommunications the EU shows an advantage. These findings demonstrate that the MFP appears to be the most important component explaining growth in high growth sectors, in particular in the services sectors. Many econometric studies have attempted to analyse the forces influencing MFP growth but they are generally confined to the study of manufacturing sectors. For example O'Mahonyet al. (2008) look at the influence of R\&D expenditure as a measure of innovative activity on MFP in the US and EU and finds comparable return to $R \& D$ across regions. However further research is needed to understand what drives differences in services sector. 
Figures 2 and 3 show the correlation between sectoral labour productivity and value added growth for the EU25 and the US. Clearly, the two variables are highly correlated by definition; however the sign of the correlation depends on the sign of the employment growth. For the majority of the industries the relationship between value added and labour productivity growth (measure as value added per hour) is positive; this correlation arises from a positive growth of both value added and labour productivity. This correlation is known in the literature as "Fabricant's Law" (see O’Mahony and Oulton, 1994).

\section{Figure 2 - Relationship Between LabourProductivity and Value Added Growth in the EU25, 1995-2007}

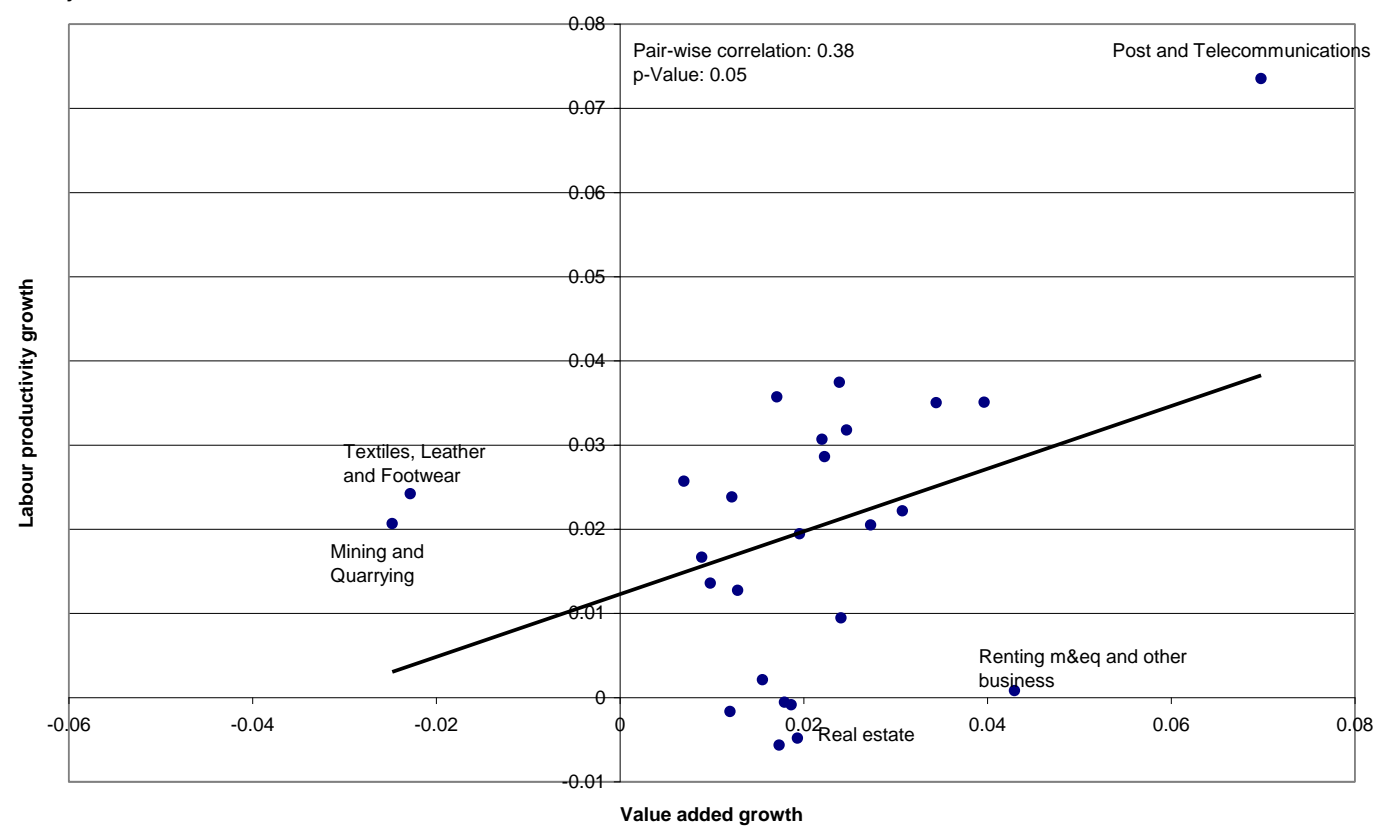

Source: EUKLEMS, November 2009 release. Own calculations.

Taking into account all the industries, the correlation is stronger in the US than in the EU25, meaning that in the US high (low) labour productivity is associated with high (low) value added growth to a larger extent than in the EU. In the EU25, post and telecommunications displays very high growth rates in terms of value added and labour productivity for the period 1995-2007, as is electrical and optical equipment. In the US, the electrical and optical equipment sector shows rates above 10 per cent in both value added and labour productivity growth.

There are a few exceptional industries that show a negative relationship between valued added and labour productivity growth. Mining and textiles, leather and footwear in the EU25 and the US are decreasing in terms of value added growth but increasing in terms of labour productivity. This is due to large decreases in employment in these 
declining industries. Construction and mining are sectors in the US that are experiencing decline both in terms of output and labour productivity.

Figure 3 - Relationship Between LabourProductivity and Value Added Growth in the US, 1995-2007

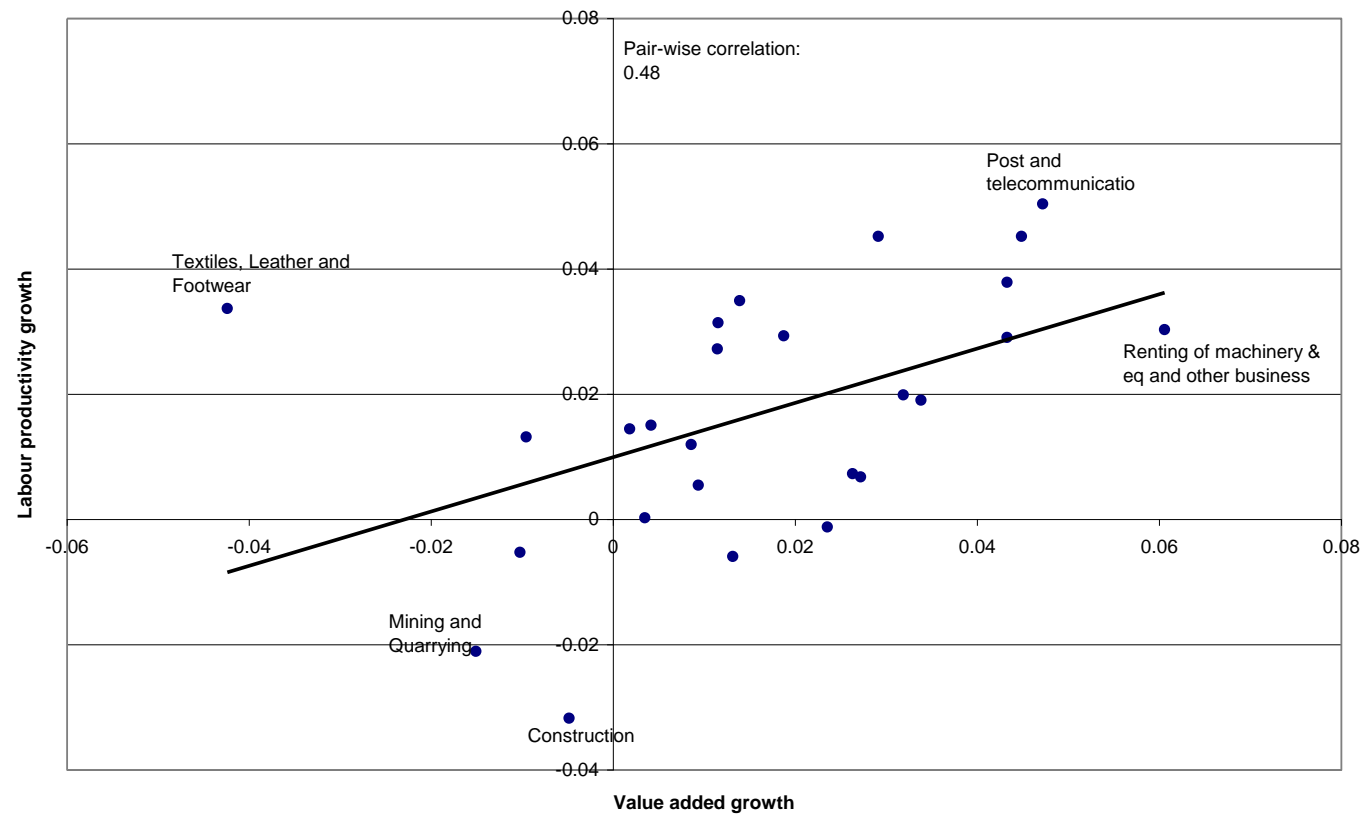

Source: EUKLEMS, November 2009 release. Own calculations.

A similar relationship also holds for labour and multifactor productivity. Figures 4 and 5 below show the positive correlation between sectoral labour productivity and multifactor productivity, in both the EU15ex and the US for the period 1995-2007. In general the sectors with high (low) labour productivity growth also show a high (low) multifactor productivity growth. The sector that shows the highest MFP and labour productivity growth rates in the EU-15ex is again post and telecommunications, followed by electrical and optical equipment ${ }^{10}$. The wholesale and retail sector shows positive but moderate growth rates in terms of both multifactor and labour productivity growth. The sector renting of machinery and equipment and other business activities is the one that performs the worst in terms of multifactor productivity. The most traditional production industries, such as mining and quarrying, show negative growth rates in multifactor productivity and positive in labour productivity.

${ }^{10}$ The electrical and optical equipment sector is not included in figures 4 and 5 . 
Figure 4 - Relationship Between Multifactor Productivity and Labour Productivity Growth in EU-15ex for 1995-2007

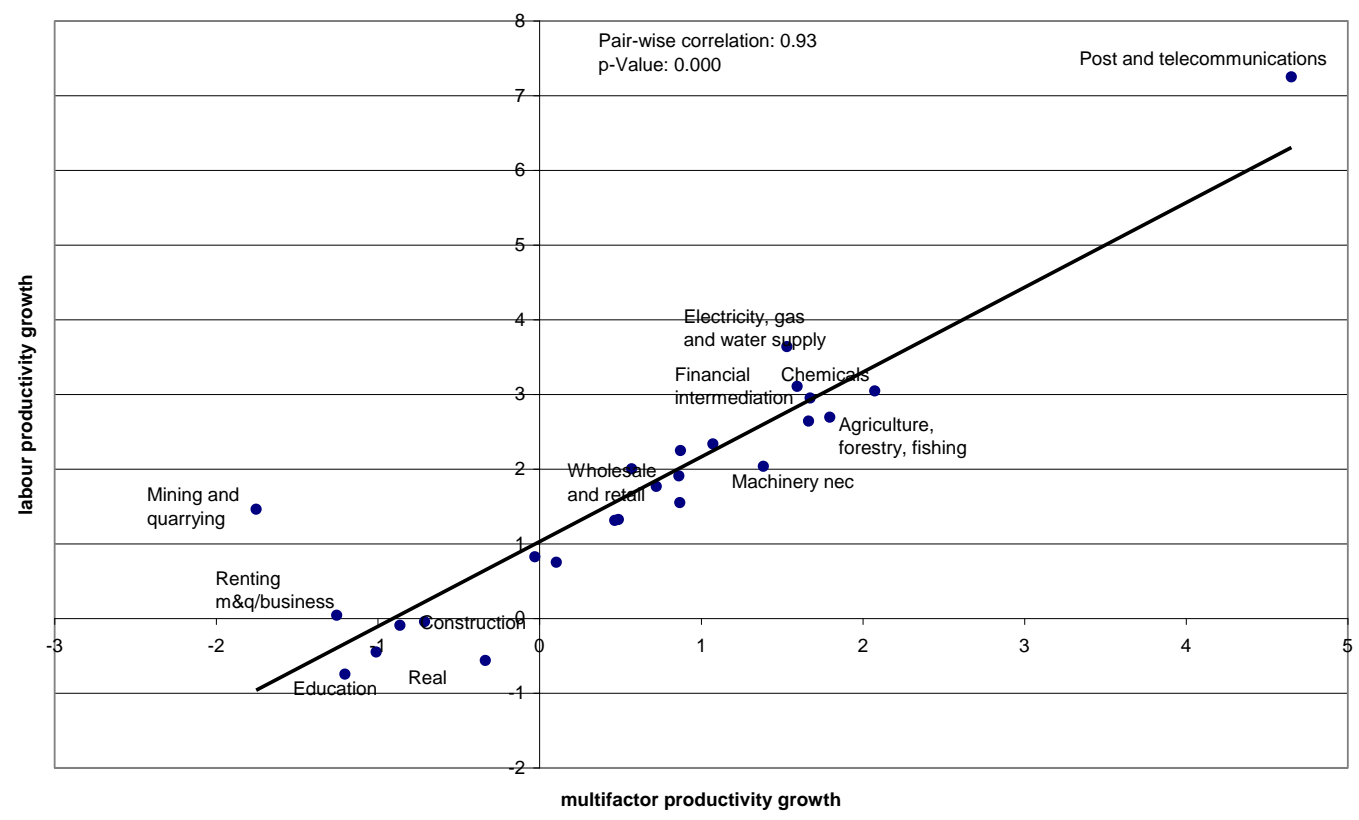

Source: EUKLEMS, November 2009 release. Own calculations.

Figure 5 - Relationship Between Multifactor Productivity and Labour Productivity Growth in the US for 1995-2007

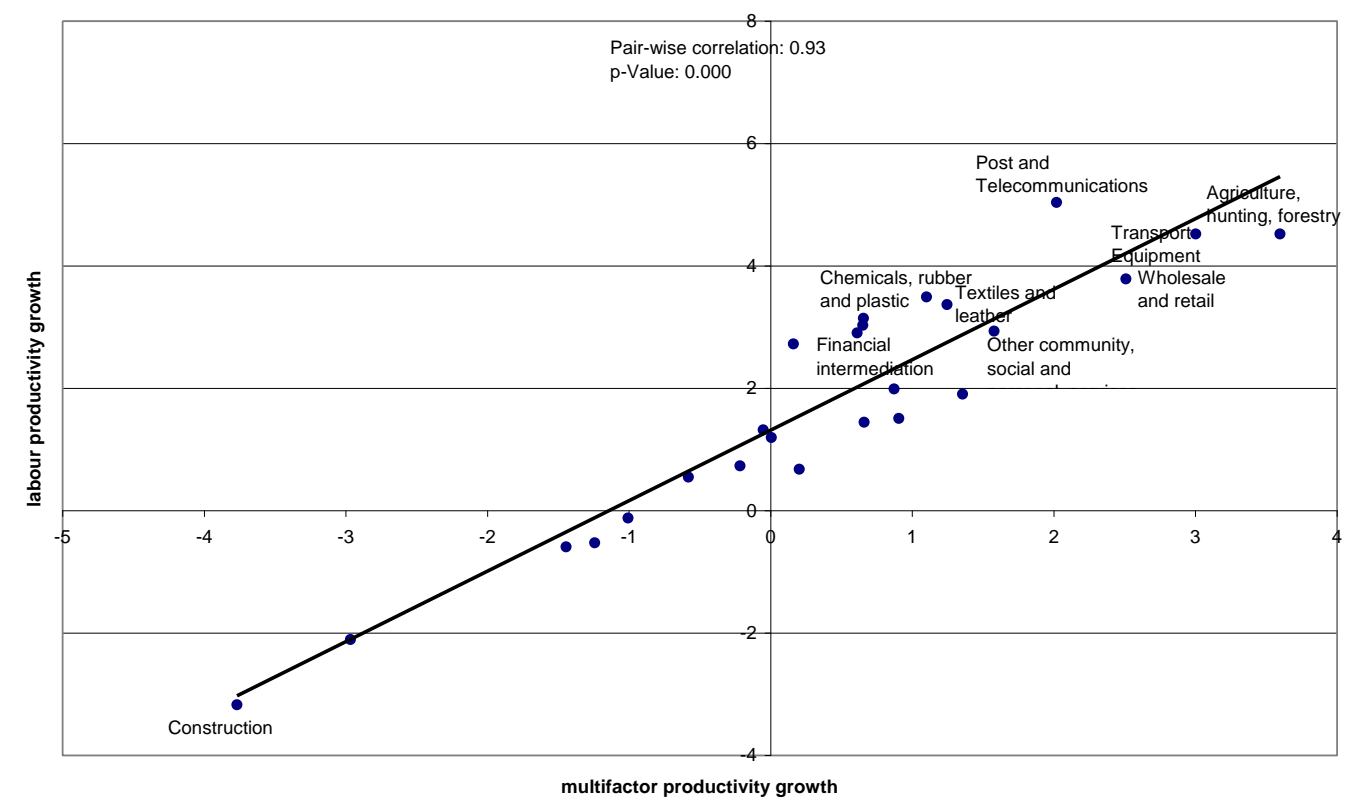

Source: EUKLEMS, November 2009 release. Own calculations.

In the US the sector that shows the highest multifactor and labour productivity growth is electrical and optical equipment, by a significant 
margin (rates of above 10 per cent). In the US many of the traditional industries show positive multifactor productivity growth alongside positive labour productivity growth. The sectors wholesale and retail and financial intermediation are also showing large positive growth rates in both variables for this period -much higher than in the EU-15ex. Overall we observe a large number of industries in the US showing large labour productivity and multifactor productivity growth rates in comparison to the EU.

\section{Conclusions}

The analysis of productivity trends is crucial to the understanding of the long-term competitiveness of Europe. This paper provides an overview of the main strengths and weaknesses of European productivity growth at the sectoral level over the period 1995-2007 relative to the US, using recent updates to EU KLEMS. A detailed exploration of EU sectoral productivity growth reveals not only a wide range of variation in the performance of sectors but also across countries. Productivity growth in the "old" EU15 have been quite moderate, while the New Member States have experienced much higher rates of growth in a large number of sectors; in many cases, higher than the US. The difference in aggregate labour productivity growth for the period 1995-2007 between the combined EU25 and the US is only around 0.23 percentage points. Thus the latest revisions to the data provide evidence of a narrower gap than previously estimated, but the gap is still substantial, particular when we look at the sectoral level.

Whilst there are some sectors in which the EU performs well the US see productivity growth more evenly distributed, especially throughout the market services. The EU has had a faster growth in labour productivity than the US in a number of traditional manufacturing sectors such as food, drink and tobacco and wood and wood products. There is a general decline in a number of traditional low technology manufacturing sectors and other production industries such as mining and agriculture. However, the EU has seen strong growth in the more high technology sectors such as chemicals and electrical and optical equipment.Sectors that are more heavily employing high technology are also showing signs of strong growth performance, such as post and telecommunications. Whilst this is encouraging, rates of growth are generally much higher in the US and its industrial structure is more concentrated in these higher growth sectors.

Whilst traditional manufacturing sectors are also important for the US, market services play a more important role. Those sectors in which the US display higher levels of growth than the EU include financial 
intermediation and the wholesale and retail sectors. The wholesale and retail sector alone accounts for three quarters of aggregate gap in labour productivity between the US and EU25. Regarding MFP developments, rapid growth in the EU compared to the US is observed in agriculture, paper, publishing and printing, chemicals, machinery n.e.c., post and telecommunications, transport and storage, as well as in a number of nonmarket service industries. However, the most striking feature of MFP growth is the poor performance in some market service sectors relative to the US. At the same time the US are also experiencing important MFP growth rates in traditional manufacturing sectors such as basic and fabricated metal products, whilst these improvements are not seen in the EU.

Thus, whilst technology has undoubtedly driven structural changes, the explanation has now moved on from technology intensive sectoral growth to growth more generally in market services, highlighting the importance of ICT as a generic, multi-purpose technology. The EU shows pockets of high growth but there is greater inequality in performance in market services.

The source of the growth appears to be MFP, suggesting that there has been substantial growth in the contributions of intangible inputs and differences in institutional and regulatory settings that can have an effect on the adoption and diffusion of latest technologies as well as hinder market mechanism of reallocation of resources. All these are likely to be important determinants for MFP developments but much research is needed to understand the determinants of MFP growth particularly in the services sectors. 


\section{References}

Arnold, J., Nicoletti, G.,\&Scarpetta, S. (2010). Much Ado About something? Regulation, Resource Allocation and Firm-level Productivity in a Panel of Countries.Paper presented at theIfo / CESifoE OECD Conference on Regulation, 29-20 January 2010, Munich.

Arnold, J., Nicoletti,G., \&Scarpetta,S. (2008).Regulation, Allocative Efficiency and Productivity in OECD Countries - Industry and Firm Level Evidence.OECD Economics Department Working Paper,616.

Arnold, J.,Javorcik,B.,\&Mattoo,A. (2007). Does Services Liberalization Benefit Manufacturing Firms? Evidence from the Czech Republic.World Bank Policy Research Working Paper Series, 4109.

Autor, D.H., Katz, L.F.,\&Krueger, A.B. (1998). Computing inequality: have computers changed the labour market? Quarterly Journal of Economics,113 (4), 1169-1210. doi:10.1162/003355398555874

Basu, S., Fernald, J.G.,Oulton,N.,\&Srinivasan,S. (2003). The case of the missing productivity growth; or why has productivity accelerated in the US but not in the UK.NBER Working Paper,10010.

Conway, P., de Rosa, D., Nicoletti, G.,\&Steiner,F. (2006). Regulation, Competition and Productivity Convergence.OECD Economics Department Working Paper, 509.

Bartelsman, E.J., Haltiwanger,J.,\&Scarpetta,S. (2009b). Cross-Country Differences in Productivity: The Role of Allocation and Selection. NBER Working Paper Series, 15490.

European Commission (2009) EU Industrial Structure 2009. Performance and Competitiveness.Luxembourg:European Commission, Enterprise and Industry.

Inklaar, R., Timmer, M.P.,\&van Ark,B. (2008). Market Services Productivity across Europe and the US.Economic Policy, 23(53), 139-194.

Jorgenson, D.W., Gollop,F.M.,\&Fraumeni,B. (1987).Productivity and US Economic Growth.Cambridge, MA:Harvard University Press.

Inklaar, R., O'Mahony, M.,\&Timmer,M. (2003). ICT and Europe's Productivity Performance: Industry-Level Growth Account Comparisons with the United States.Research Memorandum GD-68. Groningen Growth and Development Centre.

Machin, S.,\&Van Reenen,J. (1998). Technology and Changes in Skill Structure: Evidence from Seven OECD Countries.Quarterly Journal of Economics, 113(4), 1215-1244. doi:10.1162/003355398555883 
McMorrow, K.,\&Roger,W. (2007). An Analysis of EU Growth Trends, with a Particular Focus on Germany, France, Italy and the UK.National Institute Economic Review, 199(1), 82-98

Nicoletti, G., \&Scarpetta,S. (2003). Regulation, Productivity and Growth: OECD Evidence. Economic Policy, 18 (36), 9-72. doi:10.1111/1468$\underline{0327.00102}$

O'Mahony, M. (1999).Britain's Productivity Performance 1950-1996.London: NIESR.

O'Mahony, M.,\&Oulton,N. (1994). Productivity and Growth: A Study of British Industry 1954-1986. London:NIESR.

O'Mahony, M.,\&van Ark,B. (2003).EU productivity and competitiveness: An industry perspective. Can Europe resume the catching-up process? European Commission, Luxembourg: Office for Official Publications of the European Communities.

O’Mahony, M., Robinson, C.,\&Rincón-Aznar,A. (2008). Inputs to Production. In Peneder, M., (ed).Sectoral Growth Drivers and Competitiveness in the European Union.Luxembourg:European Commission, Enterprise and Industry.

O'Mahony, M.,\&Timmer,M.,(2009).Output, Input and Productivity Measures at the Industry Level: The EU KLEMS Database.Economic Journal, 119(538), F374-F403. doi:10.1111/j.1468-0297.2009.02280.x

Peneder, M. (ed) (2009).Sectoral Growth Drivers and Competitiveness in the European Union.Luxembourg:European Commission, Enterprise and Industry.

Rincón-Aznar, A., Robinson,C.,\&Loveridge,P. (2008). Productivity.In Peneder, M. (ed).Sectoral Growth Drivers and Competitiveness in the European Union.Luxembourg: European Commission, Enterprise and Industry.

Rincón-Aznar, A., Myers,B.,\&Robinson,C. (2009). ICT, Regulation and Productivity. In Competitiveness Report 2009, European Commission.

van Ark, B., O'Mahony,M.,\&Ypma, G., (eds) (2007). The EU KLEMS Productivity Report. An Overview of Results from the EU KLEMS Growth and Productivity Accounts for the European Union, EU Member States and Major Other Countries in the World, Issue 1, available at http:/ / www.euklems.net/

van Ark, B., O'Mahony,M. \&Timmer,M. (2008). The productivity gap between Europe and the US: Trends and causes.Journal of Economic Perspectives, 22(1), 25-44. doi:10.1257/jep.22.1.25 